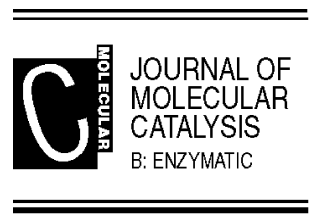

Journal of Molecular Catalysis B: Enzymatic 7 (1999) 233-239

www.elsevier.com/locate/molcatb

\title{
Effects of temperature on the cellulose binding ability of cellulase enzymes
}

\author{
J. Andreaus a,b , H. Azevedo ${ }^{\text {b,c }}$, A. Cavaco-Paulo ${ }^{\text {b,* }}$ \\ ${ }^{\text {a }}$ Textil Alberto de Sousa, S.A., Vila Nova de Sande, Guimarães, Portugal \\ ${ }^{\mathrm{b}}$ Department of Textile Engineering, University of Minho, 4800 Guimarães, Portugal \\ ${ }^{\mathrm{c}}$ Department of Textiles and Fashion, De Montfort University, Leicester LE1 9BH, UK
}

\begin{abstract}
The effects of high temperatures on catalytic activity and binding abilities of crude Trichoderma reesei cellulases in solution and adsorbed to a cotton fabric were studied. Above optimum temperature of $50^{\circ} \mathrm{C}$, catalytic activities were severely diminished but the binding behaviour was not found to be adversely affected. In order to verify possible applications of cellulases adsorbed to cotton fabrics as anchors for textile finishing purposes, we also checked the binding abilities after ironing. Previous ironing of cellulase adsorbed fabrics increased dyeability with an acid dye, but dye fastness was poor. Desorption of cellulases from cotton fabrics increased from $\mathrm{pH} 5$ to $\mathrm{pH}$ 10. Dry ironing of fabrics resulted in less desorption, whereas wet ironing inhibited desorption at $\mathrm{pH} 5$ and only $11 \%$ of protein were desorbed at $\mathrm{pH} 10$. Ironing of the fabrics diminished enzyme activity of desorbed cellulases. Wet ironing resulted in complete denaturation of the proteins and no cellulolytic activity was found. The presence of water during thermal treatment of cellulases was found to be essential for complete denaturation and unfolding of the proteins. Dry heat only resulted in partial denaturation. Fluorescence measurements of cellulases adsorbed to cotton fabrics showed after ironing a significant shift in tryptophan fluorescence to higher wavelengths. This indicates unfolding and denaturation of the enzymes and revelation of more hydrophobic amino acids to the surface, which enables increased hydrophobic interactions with the fabric. (c) 1999 Elsevier Science B.V. All rights reserved.
\end{abstract}

Keywords: Trichoderma reesei; Cellulases; Binding ability; Ironing; Cellulose binding domain (CBD); Dye affinity of cellulases; Deactivation; Denaturation; Hydrophobic interactions; Tryptophan fluorescence

\section{Introduction}

Cellulase enzymes are widely used for textile and detergent applications to improve the properties of cellulose-based textiles. The stone washed look of denim garments, improved colour brightness and depilling effects are the most successful applications of these enzymes

\footnotetext{
* Corresponding author
}

$[1,2]$. The benefits of the effects delivered by cellulases are the result of controlled action of the enzymes on the cellulose fibres. Adsorption to the insoluble substrates is a fundamental step in the hydrolytic action of the enzymes. In fact, cellulases are known to have two structurally different domains linked by a peptide: a catalytic domain and a cellulose-binding domain (CBD). According to amino acid homologies and similarities in 3D structures, catalytic do- 
mains have been grouped into several families. ${ }^{1}$ CBDs, which play an important role in binding to cellulose substrates, have been divided on the basis of their amino acid sequence into 5 families [4]. The cellulolytic enzyme system of Trichoderma reesei consists of three different types of enzymes (endoglucanases (EG), cellobiohydrolases $(\mathrm{CBH})$ and $\beta$-glucanases) and 4 major catalytic components (EGI, EGII, CBHI, CBHII) [5]. T. reesei cellulases have a maximum activity at $\mathrm{pH} 5$ and $50^{\circ} \mathrm{C}[6]$ and their catalytic domain is deactivated beyond the temperature of maximum activity [7]. The binding ability of isolated CBDs of $T$. reesei cellulases, which belong to $\mathrm{CBD}$ family $\mathrm{I}$, was reported to be reversible and to show a higher affinity for cellulose substrates at lower temperatures [8].

In this work we investigated the catalytic and binding abilities of $T$. reesei cellulases in solution and adsorbed to a cotton fabric after thermal treatment. In order to verify the possibility of using adsorbed cellulases as anchors to other textile finishers we have also checked the binding ability of cellulases bound to cotton fabrics after ironing. Dyeability and washing fastness of such treated fabrics were tested. We also studied the reversibility of adsorption to a cotton fabric at different $\mathrm{pHs}$ and after different ironing procedures.

\section{Materials and methods}

\subsection{Determination of binding and activity pro- files}

$0.6 \mathrm{ml}$ of a total crude mixture of cellulases from $T$. reesei (Röhm Enzyme Finland OY) cellulases were dissolved in $100 \mathrm{ml}$ acetate buffer $(\mathrm{pH} 5,0.1 \mathrm{M})$ and treated at different temperatures for $5 \mathrm{~h}$. Pieces of $100 \%$ scoured and bleached cotton fabric were incubated for 1

\footnotetext{
${ }^{1}$ http:/ / expasy.hcuge.ch/cgi-bin/lists?glycosid.txt, for associated references, see Refs. [3,16-18].
}

$\mathrm{h}$ at $50^{\circ} \mathrm{C}$ in a Rotawash machine with the pre-treated cellulases. Reducing soluble sugars were measured as described before [6]. Protein contents on the fabrics were measured by modified Lowry procedure [9].

\subsection{Preparation of the cellulase adsorbed fab- rics}

A mercerised cotton fabric, pre-washed with water for $20 \mathrm{~min}$ at $50^{\circ} \mathrm{C}$, was incubated at ambient temperature $\left(20-25^{\circ} \mathrm{C}\right)$ for $20 \mathrm{~min}$ in 101 of a buffered (acetate buffer, $\mathrm{pH} 4.8-4.9$ ) solution with a total crude mixture of cellulases from T. reesei (Röhm Enzyme Finland OY) in a domestic washing machine. The reference fabric was just washed with buffer. Fabrics were centrifuged and line dried. The protein amount adsorbed to the fabric was $8.07 \mathrm{mg} / \mathrm{g}$ measured by modified Lowry method [9].

Dried fabrics were stored under controlled conditions $\left(T=21^{\circ} \mathrm{C}\right.$, humidity $\left.=70-80 \%\right)$. To stop enzyme activity and to wash off proteins, parts of the fabric were washed in $5 \% \mathrm{Na}_{2} \mathrm{CO}_{3}$ at $50-70^{\circ} \mathrm{C}$ during $20 \mathrm{~min}$.

For preparation of fabrics and experiments with $\mathrm{CBD}_{\mathrm{CenA}}$ of Cellumonas fimi, see Ref. [10].

\subsection{Ironing of fabrics}

Cellulase adsorbed fabrics were ironed 5 times on each side with or without previous wetting (with tap water) with a common household iron adjusted to cotton ironing temperature $\left(\sim 150^{\circ} \mathrm{C}\right)$.

\subsection{Dyeing, washing and desorption tests}

Fabric samples of $1 \mathrm{~g}$ were dyed in $25 \mathrm{ml}$ aqueous solution (liquor ratio $=1: 25 ; \mathrm{pH} 5.8$ ) of $2 \%$ (dye/fabric) Coomassie Brilliant Blue $250 \mathrm{G}$ in an Ahiba Datacolor dyeing machine (40 rpm). Dyeing was started at $30^{\circ} \mathrm{C}$; temperature was risen to $60^{\circ} \mathrm{C}$ at a rate of $1^{\circ} \mathrm{C} / \mathrm{min}$ and 
was held there for $60 \mathrm{~min}$. Afterwards fabrics were rinsed with cold water and dried.

Dye fastness was tested according to a variation of standard procedure ISO 105-CO3-1978.

Washing tests were carried out in an Ahiba Datacolor dyeing machine $(70 \mathrm{rpm})$ at $60^{\circ} \mathrm{C}$ for 30 min with (1) distilled water and (20) an aqueous solution of $5 \mathrm{~g} / 1$ of neutral standard soap plus $2 \mathrm{~g} / 1 \mathrm{Na}_{2} \mathrm{CO}_{3}$. Reflectance $(K / S)$ was measured before and after washing with an ACS Chroma Color Spectrometer at $600 \mathrm{~nm}$ at 3-5 different points of the sample.

For desorption tests $1 \mathrm{~g}$ of cellulase adsorbed fabric was washed in a Rotawash machine (40 $\mathrm{rpm}, 1 \mathrm{~h}$ at $30^{\circ} \mathrm{C}$ and another hour at $50^{\circ} \mathrm{C}$ ) with $50 \mathrm{ml}$ of aqueous buffer solutions $(\mathrm{pH} 5: 0.1 \mathrm{M}$ $\mathrm{CH}_{3} \mathrm{COOH} / \mathrm{NaOH}, \mathrm{pH}$ 7: $0.01 \mathrm{M} \mathrm{KH}_{2} \mathrm{PO}_{4} /$ $\mathrm{NaOH}$ and $\mathrm{pH}$ 10: $0.005 \mathrm{M} \mathrm{NaHCO}_{3} / 0.01 \mathrm{M}$ $\mathrm{NaOH})$.

Protein in solution was measured by Bradford method [11], reducing soluble sugars were analysed as described before [9].

\subsubsection{Fluorescence measurements}

Fluorescence spectra of protein adsorbed cotton fabrics (untreated, dry and wet ironed) were measured with an excitation wavelength $\lambda_{\text {exc }}$ of $296 \mathrm{~nm}$ on a Perkin Elmer Spectrophotometer with a reflectance facility.

\section{Results and discussion}

The activity and the binding behaviour of total crude cellulases of $T$. reesei on cotton fabrics were measured after thermal pre-treatment during $5 \mathrm{~h}$ in the range from 37 to $80^{\circ} \mathrm{C}$. The activity of the enzymes, measured by the formation of reducing soluble sugars, was not affected until $37^{\circ} \mathrm{C}$, was slightly reduced $(-20 \%)$ between 37 and $50^{\circ} \mathrm{C}$ and decreased sharply above $50^{\circ} \mathrm{C}$. Above $70^{\circ} \mathrm{C}$ almost no activity was found. This coincides with results reported by Baker et al. [7], who studied the activity of purified enzyme components of $T$. reesei on various substrates. The resting activity after thermal pre-treatment above $70^{\circ} \mathrm{C}$ can be ascribed to the activity of the more thermostable cellulase component EG II, which constitutes around $3 \%$ of the total crude mixture. For EG II, Baker et al. [7] reported a $T_{\mathrm{m}}$ of $75^{\circ} \mathrm{C}$ (temperature at which half of the protein is denatured), which is around $10^{\circ} \mathrm{C}$ higher than for the other cellulase components ( $\mathrm{CBH} \mathrm{I}$, $\mathrm{CBH}$ II, EG I). Deactivation of the cellulases occurs due to denaturation of the enzymes and especially unfolding of the catalytic domain [7].

Whereas the catalytic activity of the cellulases is almost completely inhibited at higher pre-treatment temperatures, the binding behaviour was found to be hardly affected. In contrast, completion of enzyme denaturation seemed to increase its binding ability to cotton fabric (see Fig. 1).

As it was already shown for bacterial cellulases $[9,10]$, the dye affinity of a fabric can be increased by adsorbed cellulase proteins. This effect is due to the increased presence of ionic groups on the fabric. We studied the effect of previous dry and wet ironing on the staining levels of fabrics adsorbed with $T$. reesei cellulases. As it was already found for the CBDs of

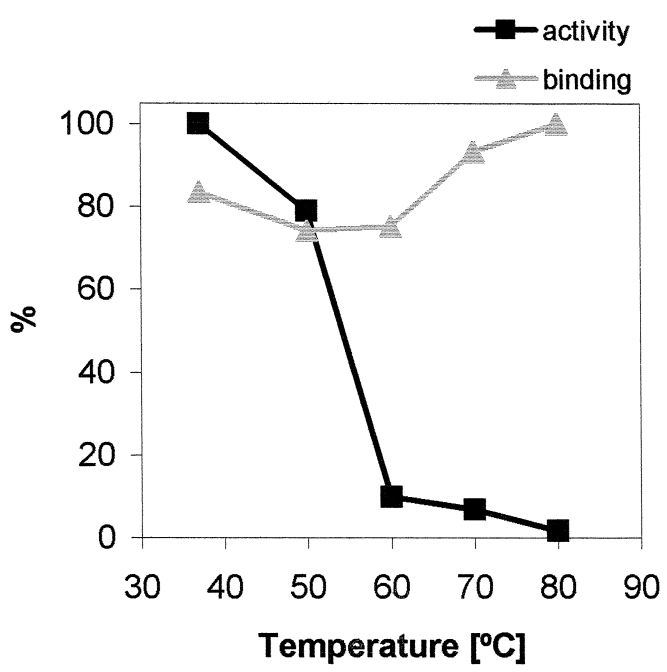

Fig. 1. Activity and binding profiles (in \% of maximum value) of T. reesei total crude cellulases on cotton fabrics after previous incubation without fabrics during $5 \mathrm{~h}$ at temperatures in the range of $37-80^{\circ} \mathrm{C}$. 


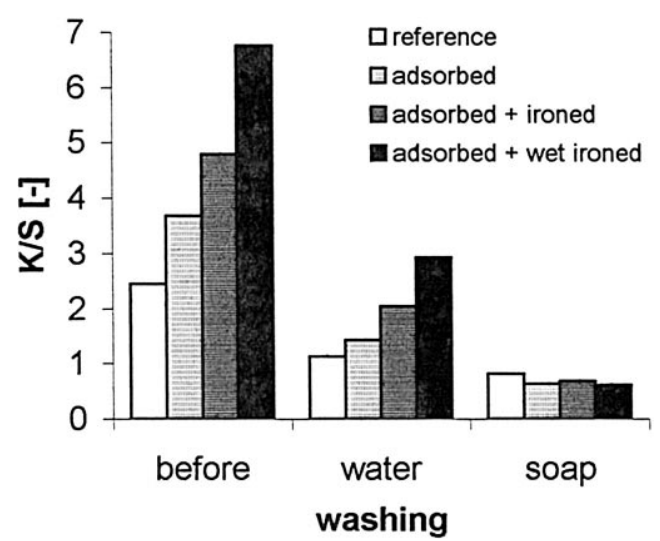

Fig. 2. Staining levels $(K / S$ at $600 \mathrm{~nm})$ of Coomassie Brilliant Blue G250 dyed cotton fabrics adsorbed with total crude cellulase mixtures of $T$. reesei before and after washing (Ahiba Datacolor dyeing machine, $70 \mathrm{rpm} ; 60^{\circ} \mathrm{C} ; 30 \mathrm{~min}$ ) with distilled water or soap $\left(5 \mathrm{~g} / 1\right.$ neutral standard soap $\left.+2 \mathrm{~g} / 1 \mathrm{Na}_{2} \mathrm{CO}_{3}\right)$.

bacterial cellulases [10], the affinity for the acid dye Coomassie Brilliant Blue G250 was increased by ironing of the fabrics before dyeing. Whereas dry ironing increased staining levels of fabrics adsorbed with $\mathrm{CBD}_{\mathrm{CenA}}$ of $C$. fimi in average only by $18 \%$, dye affinity of fabrics adsorbed with complete cellulases of $T$. reesei was augmented by $56 \%$ (see Fig. 2). One reason may be that the peptide of $C$. fimi CBD is just around 110 units long, whereas the amino acid chain of the complete cellulases including CBD, linker and catalytic domain is much longer. Anyhow, comparison is difficult, since protein contents on the fabrics were not the same and differences in the reversibility of adsorption behaviour might have some influence during dyeing $[8,10]$.

Ironing of the fabrics as a kind of thermal treatment is supposed to denature and unfold the proteins and thus may cause two different effects,

(1) More ionic groups of the proteins become exposed to the surface and are available to dye fixation.

(2) More tryptophan residues formerly hidden inside the 3D-structure are revealed and thus may lead to an increase in hydrophobic interactions between protein and fabric.
Washing of the enzyme treated and dyed fabrics with neutral soap $+\mathrm{Na}_{2} \mathrm{CO}_{3}$ removed more than $80 \%$ of the colour. Washing with water reduced staining levels $(K / S$ values at $600 \mathrm{~nm}$ ) by at least $50 \%$. Differences in staining levels after washing are due to the formation of micelles formed by neutral soap, which are able to solubilize more dye and avoid its redeposition on the fabric. Anyhow, after washing with water previously ironed fabrics showed still more than $40 \%$ and wet ironed fabrics even more than $100 \%$ higher staining levels than not ironed fabrics (see Fig. 2). These differences may be ascribed to an increase in hydrophobic interactions between hydrophobic amino acids revealed by denaturation through ironing and the cotton fabric. After washing with neutral soap slightly more colour remained on the reference fabrics than on the enzyme treated fabrics (see Fig. 2). This may be explained by the fact, that the surface of enzyme treated fabrics is covered by cellulases and most of the dye interacts with the cellulases, which are obviously well solubilized by soap micelles, whereas on the reference fabric the acid dye interacts directly with the cellulose, migrates into the structure and thus is more difficult to remove. The assumption of unfolding and revealing of hydrophobic amino acids through ironing could be confirmed by measurements of tryptophan fluorescence on the dry fabrics. Ironing of fabrics adsorbed with total crude cellulases resulted in a significant shift in tryptophan fluorescence of 6 $\mathrm{nm}$ to higher wavelengths (see Table 1). With fabrics adsorbed with $1.38 \mathrm{mg} / \mathrm{g} \mathrm{CBD}_{\mathrm{CenA}}$ of C. fimi [10], no shift was observed. This may be

Table 1

Fluorescence maximums of fabrics adsorbed with different proteins with and without posterior ironing $\left(\lambda_{\text {exc }}=296 \mathrm{~nm}\right)$

\begin{tabular}{llll}
\hline Sample & \multicolumn{3}{l}{ Fluorescence maximum $\lambda_{\max }(\mathrm{nm})$} \\
\cline { 2 - 4 } & Adsorbed & Ironed & Wet ironed \\
\hline TC & 338 & 344 & 340 \\
BSA & no maximum & no maximum & no maximum \\
reference & no maximum & no maximum & no maximum \\
\hline
\end{tabular}


explained by the fact that $C$. fimi CBDs belong to family II and 3 of its 6 tryptophan residues are already exposed to a more hydrophilic environment since they are located on the outer side of the 3-dimensional structure [12]. So the probability to reveal additional tryptophan residues by denaturation is much lower than for the entire cellulase enzyme. Differences in the shifts of tryptophan fluorescence between CBDs and entire cellulases also coincide well with the differences found in staining levels before and after ironing (see above). Reference fabrics without protein and fabrics adsorbed with 3.2 $\mathrm{mg} / \mathrm{g}$ BSA protein did not show any maximum in the range of maximum tryptophan fluorescence (320-350 nm). Responsible for the different behaviour of BSA might be the differences in protein structure and adsorption mechanism (no CBD).

Tryptophan fluorescence is a sensitive function of the polarity of the microenvironment of a given residue [13]. A shift of the maximum of emission to higher wavelengths means a change to a more polar environment. This principle is used to detect the transfer of tryptophan side chains from the interior of a relatively hydrophobic environment of a folded, native protein to a mostly aqueous and thus polar environment of an unfolded, random-coiled protein structure. If there are more tryptophan residues, fluorescence emission is the sum of all tryptophan residues. Baker et al. [7] found comparable results for the denaturation of $T$. reesei components in solution. Since polarity in aqueous solution should be expected to be much higher than on a dried fabric, effects on fluorescence in solution are more announced. Wet ironed fabrics gave still a higher emission maximum than not ironed fabrics, but we cannot explain why shifts were smaller than from dry ironed fabrics (see Fig. 3).

The effect of ironing on the reversibility of the adsorption of $T$. reesei cellulases was investigated by washing the fabrics in buffer solutions of different $\mathrm{pH}\left(\mathrm{pH} \mathrm{5,7}\right.$ and 10) at $30^{\circ}$ and $50^{\circ} \mathrm{C}$ and at high levels of mechanical action.

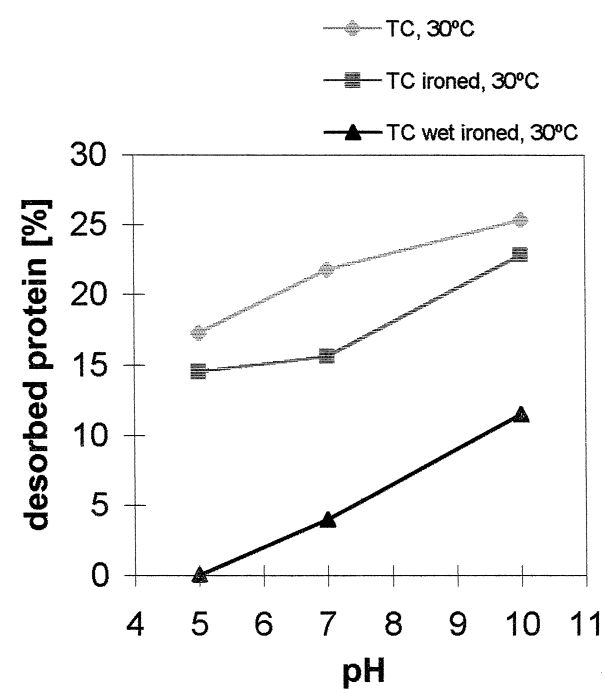

Fig. 3. Desorption of total crude mixture cellulases of T. reesei (in $\%$ of initially adsorbed protein) from mercerised cotton fabrics with buffer solutions of different $\mathrm{pH}$. Desorption experiments were carried out with $1 \mathrm{~g}$ of fabric and $50 \mathrm{ml}$ of buffer solution in a Rotowash machine $\left(40 \mathrm{rpm} ; 30^{\circ} \mathrm{C} ; 1 \mathrm{~h}\right)$.

Desorption was calculated in \% of initially adsorbed protein. Under alkaline conditions at $\mathrm{pH}$ $1025 \%$ of initially adsorbed protein was found in solution. Dry ironing of fabrics before washing resulted in reduced desorption (up to $20 \%$ less compared to the non ironed fabrics), whereas after wet ironing no protein was desorbed with pH 5 elution buffer and only $11 \%$ of initial protein were desorbed at $\mathrm{pH} 10$. It seems, that the presence of water during ironing is essential for complete unfolding of the adsorbed cellulases, whereas ironing under dry conditions only results in partial denaturation of the proteins. Water serves during ironing as a medium for heat transfer and thus facilitates denaturation of all adsorbed protein. Since we did not wash fabrics after desorption, more than one protein layer might be adsorbed to the fabric. Without water probably only the exposed protein molecules on the outer surface of the cotton fabric are affected by ironing. As a conclusion more hydrophobic interactions are possibly formed between fabric and cellulases, when fabrics are wet ironed and all protein is unfolded. Thus, less desorption is observed. Furthermore, 
the importance of water during ironing for denaturation of the proteins may be compared to the effect of water on the activity of enzymes in non-aqueous media, where a thermodynamic water activity $\left(a_{\mathrm{w}}\right)$ or water content is considered to be decisive for the mobility and catalytic activity of the enzymes [14]. The water activity is a parameter, which quantifies the amount of water bound to the enzyme molecules. We suppose that for complete unfolding by ironing a critical amount of water is necessary. Below this amount of water insufficient heat transfer occurs and less protein is denatured. Probably the flexibility of the enzyme plays an important role during denaturation.

During desorption experiments the effect of ironing on the activity of desorbed cellulases was determined by measuring reducing soluble sugars. As fabrics were incubated in two steps first at $30^{\circ} \mathrm{C}$ for $1 \mathrm{~h}$ and second at $50^{\circ} \mathrm{C}$ for another hour, we could distinguish between pure solubilization of reducing sugars formed during storage of the fabric and remaining enzyme activity after desorption. Enzyme activity (calculated in $\mathrm{mg}$ reducing soluble sugars per $\mathrm{mg}$ initially adsorbed cellulases to $1 \mathrm{~g}$ of fabric)

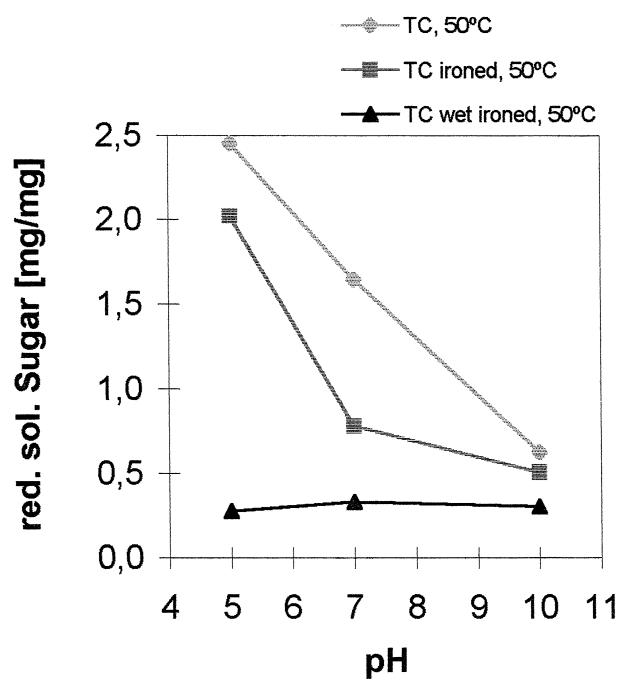

Fig. 4. Activity of desorbed enzymes measured in $\mathrm{mg}$ reducing soluble sugars per mg initially adsorbed protein. One gram of fabric was washed in $50 \mathrm{ml}$ buffer solution for $1 \mathrm{~h}$ at $30^{\circ} \mathrm{C}$ and another hour at $50^{\circ} \mathrm{C}$ at $40 \mathrm{rpm}$ in a Rotawash machine. of non-ironed fabrics was highest at $\mathrm{pH} 5$ and decreased linearly with increasing $\mathrm{pH}$ of the elution buffer (see Fig. 4). Cellulase activities determined from dry ironed fabrics were significantly lower at pHs 5 and 7. From wet ironed fabrics no differences in reducing soluble sugars due to $\mathrm{pHs}$ of elution buffers were found. Values were even below amounts found in $\mathrm{pH} 10$ buffer solutions of non-ironed and dry ironed fabrics. The amounts of reducing soluble sugars that were found in elution buffers of wet ironed fabrics might be ascribed to enzymatic degradation during preparation and storage of the cellulase adsorbed fabrics. Otter et al. [15] reported, that at alkaline $\mathrm{pH}$ cellulases are probably either inactivated during desorption or desorbed enzymes are inactivated rapidly afterwards. This would also explain the slightly higher amounts of reducing sugars found at $\mathrm{pH} 10$ from nonironed fabrics. Anyhow enzyme activity at $\mathrm{pH}$ 10 should be expected to be almost zero.

\section{Conclusion}

Thermal treatment of cellulases of $T$. reese $i$ dissolved in solution or adsorbed to a cotton fabric leads to deactivation of the enzymes and reduced catalytic activity, but does not negatively affect its binding ability to cotton fabrics. In contrast the unfolding of the protein structure of the catalytic domain turns hydrophobic amino acids from the interior to the surface and enables the formation of more hydrophobic interactions with a cotton fabric. In the same way, more ionic groups are available to dye fixation, so that dyeability with an acid dye was increased. The formation of more hydrophobic interactions between the cellulases and the fabric also constitutes more resistance to desorption. The presence of water during thermal treatment of cellulases is essential for complete denaturation and unfolding of the protein, whereas application of heat under dry conditions only leads to partial denaturation. Proba- 
bly a critical amount of water exists, below which insufficient heat transfer to the enzymes and incomplete denaturation occurs.

\section{Acknowledgements}

We would like to thank Röhm Enzymes for supply of Trichoderma reesei enzymes, Dr. João Queiroz for his helpful assistance during fluorescence measurements and the EU-TMR programme for providing the grant of Dr. Jürgen Andreaus.

\section{References}

[1] A. Cavaco-Paulo, Processing Textile Fibers with Enzymes, in: K.E. Eriksson, A. Cavaco-Paulo (Eds.), ACS Symp. Series 687, 1998, p. 180.

[2] K. Maurer, Development of New Cellulases, in: M. Dekker, J.H. van Ee, O. Misset, E.J. Baas (Eds.), Surfactant Science Series 69, 1997, p. 175.

[3] B. Henrissat, Biochem. J. 280 (1991) 309.
[4] J.B. Coutinho, N.R. Gilkes, R.J. Warren, D.G. Kilburn, R.C. Miller Jr., Mol. Microb. 6 (1992) 1243.

[5] T. Reinikainen, K. Henriksson, M. Siika-aho, O. Teleman, K. Poutanen, Enzyme Microb. Technol. 17 (1995) 888.

[6] A. Cavaco-Paulo, L. Almeida, D. Bishop, Tex. Res. J. 68 (1998) 273.

[7] J.O. Baker, K. Tatsunoto, K. Grohmann, J. Woodward, J.M. Wichert, S.P. Shoemaker, M.E. Himmel, Appl. Biochem. Biotechnol. 34-35 (1992) 217.

[8] M. Linder, T. Teeri, Proc. Natl. Acad. Sci. USA 93 (1996) 12251.

[9] A. Cavaco-Paulo, J. Morgado, L. Almeida, D. Kilburn, Textile Res. J. 68 (1998) 398.

[10] A. Cavaco-Paulo, J. Morgado, J. Andreaus, D. Kilburn, Book of Abstracts of AATCC Conference 1998, Philadelphia, p. 500.

[11] M. Bradford, Anal. Biochem. 72 (1976) 248.

[12] G. Xu, E. Ong, N.R. Gilkes, D.G. Kilburn, D.R. Muhandiram, M. Harris-Brandts, J.P. Carver, L.E. Kay, T.S. Harvey, Biochemistry 34 (1995) 6993.

[13] Protein Structure, in: T.T. Creighton (Ed.), IRL Press, Oxford, 1989.

[14] A.M.P. Koskinen, A.M. Klibanov, Enzymatic Reactions in Organic Media, Blackie Academic and Professional, an Imprint of Chapman \& Hall, Glasgow, 1996, pp. 14 and 49.

[15] D. Otter, P.A. Munro, G.K. Scott, R. Geddes, Biotechnol. Bioeng. 34 (1989) 291.

[16] B. Henrissat, A. Bairoch, Biochem. J. 293 (1993) 781.

[17] B. Henrissat, A. Bairoch, Biochem. J. 316 (1996) 695.

[18] G. Davies, B. Henrissat, Structure 3 (1995) 853. 